\title{
Effects of planting techniques on tuber yield of potato under charland
} ecosystem

\author{
MA Hossain ${ }^{1 *}$, MK Islam ${ }^{1}$, MUS Khatun ${ }^{1}$, MM Sultana $^{2}$, MR Ali ${ }^{3}$ \\ ${ }^{1}$ Scientific Officer, OFRD, BARI, Rangpur, ${ }^{2}$ Scientific Officer, SSD, BARI, Joydebpur and ${ }^{3}$ Program Officer, \\ CIP, Jessore, Bangladesh
}

\begin{abstract}
Sustainable development in potato production is an issue of growing concern. Today, population growth, the need to further the cause of human food, agricultural and energy development in the agriculture sector is. Excessive consumptionof food demand huge population the lack of stability in the future willproduce. The effect of planting technique on the yield of potato at charland ecosystem has been investigated. A field experiment was conducted at the MLT site Ulipur during rabi season 2012-13 and 2013-14 to observe the suitable planting techniques on tuber yield of potato at charland ecosystem. Four planting techniques viz., recommended system of planting $(60 \mathrm{~cm} \times 30 \mathrm{~cm})$, Single eye planting $(30 \mathrm{~cm} \times 10 \mathrm{~cm})$, Single eye double row zigzag system $(10 \mathrm{~cm} / 30 \mathrm{~cm} \times 10 \mathrm{~cm})$, and Half cut system $(30 \mathrm{~cm} \times 10 \mathrm{~cm})$, were evaluated for this purpose. The experiment was laid out in a randomized complete block design with six dispersed replications. Among the tested planting techniques, the highest tuber yield $\left(29.0 \mathrm{t} \mathrm{ha}^{-1}\right)$ was obtained from recommended system of planting and the lowest yield was obtained from single eye planting $\left(22.5 \mathrm{t} \mathrm{ha}^{-1}\right)$ system. The highest gross return (Tk.217500 ha $\left.{ }^{-1}\right)$ and gross margin $\left(\mathrm{Tk} .75000 \mathrm{ha}^{-1}\right)$ were obtained from recommended system of planting.
\end{abstract}

Key words: Planting technique, tuber yield, charland ecosystem

Progressive Agriculturists. All rights reserve

*Corresponding Author: mafzal.bari@gmail.com

\section{Introduction}

Potato (Solanum tuberosum L) is an annual, herbaceous, tuber crop of family Solanaceae that contains all the essential food ingredients required for maintaining proper health. Potato is the world's leading vegetable crop and is grown in $79 \%$ of the world's countries (FAO, 1986). It is second to maize in terms of the number of producing countries and fourth after wheat, maize and rice in global tonnage. The average composition of the potato is about $80 \%$ water, $2 \%$ protein, and $18 \%$ starch. As a food, it is one of the cheapest and easily available sources of carbohydrates and proteins and contains appreciable amount of vitamins $\mathrm{B}$ and $\mathrm{C}$ as well as some minerals. Moreover, protein of potato is of high biological value (Gandapur, 1995) and (Woolfe, 1987). In one form or another, there can hardly be any table in the world, where this vegetable is not served as a food item (Horton, 1987) and (Ivins \& Milthope, 1963). Potato is becoming increasingly important crop, as it is staple food in most of the European countries and is a good and cheap source of food calories and its high starch content can meet the energy requirements of the people living in food deficit countries (Maikhuri et al, 1996 and Van Der Zaag \& Horton, 1983). Accredited to its short duration, nutritional superiority and high amount of food per unit area and time, potato production in developing countries has been increased by about $25 \%$ over the last 4 decades.

Potato (Solanum tuberosam L.) is one of the most important horticultural and economical food crop in Bangladesh as well as many countries of the world. In Bangladesh potato is still used as a major vegetable crop. In Bangladesh potato substantially 
supplements of food requirements of the country after two cereals, rice and wheat (Sarker and Mostafa, 2002). At present potato is the most important crop that grows well throughout thecountry occupying $3^{\text {rd }}$ position after rice and wheat. Potato ranks $1^{\text {st }}$ as vegetable in terms of area and production in Bangladesh. Potato is the third largest food crop in Bangladesh and has recently occupied an important place in the list of major food and cash crops of Bangladesh (Ali and Haque, 2011). The area and production of potato in Bangladesh during 2009-2010 were 0.47 million hectares and 8.40 million MT, respectively. It is grown more or less in all the districts of Bangladesh But, better produced in the districts of Munsiganj, Bogra, Rangpur, Dinajpur and some parts of greater Comilla. The highest area concentration of potato was in Bogra (48700 hectares) in 2008-2009. This was followed by Rangpur (41200 hectares), Dinaipur (36955 hectares) and Munshiganj (32850 hectares) during the same year (BBS, 2009).Per hectare yield of potato remained static at around 12.92 MT up to 20002001. However, the increased yields of $17.80 \mathrm{MT}$ per hectare during 2009-2010 were mainly due to use of quality seeds of modern varieties and appropriate production technologies (DAE, 2010).Yield in potato as in other crops, is a very complex character and is dependent on many other characters (Mondal, 2003). The environment has many influences over productivity of potato cultivation.

Potato is the most widely grown tuber crop in Bangladesh. Farmers of all parts of the country grow potato. Farmers produce potato as a cash crop and it occupies 3.09 percent of the total cultivated land (Shahabuddin and Dorosh, 2001). But method of Potato cultivation varies from one location to other and accordingly yield varies with location. Particularly size and type of seed tuber is one of the major reasons for yield variation. Farmers in some areas use whole tuber while cut tuber in some areas. Single eye planting with closer spacing is a common practice of growing of potato at char areas. Introduction of suitable HYV of different crops along with appropriate agronomic management practices would be boost up the productivity of char areas.
Question was whether traditional practice of growing potato in char lands were better than recommended practice or not. Keeping this point in view, this experiment was conducted to find out the suitable planting techniques of potato for char lands.

\section{Materials and Methods}

The experiment was conducted at the MLT site Ulipur during Rabi season 2012-13 \& 2013-14. The land was medium high and the soil was sandy loom in texture which belongs to AEZ No 3. Four treatments were tested in RCBD with six replications. The treatments were as follows $\mathrm{T}_{1}=$ Recommended system of planting $(60 \mathrm{~cm} \times 30 \mathrm{~cm})$, $\mathrm{T}_{2}=$ Single eye planting $(30 \mathrm{~cm} \times 10 \mathrm{~cm}), \mathrm{T}_{3}=$ Single eye double row zig-zag system $(10 \mathrm{~cm} / 30 \mathrm{~cm} \times 10 \mathrm{~cm})$, and $\mathrm{T}_{4}=$ Half cut system $(30 \mathrm{~cm} \times 10 \mathrm{~cm})$. The unit plot size was $3 \mathrm{~m} \times 4 \mathrm{~m}$. Potato variety cardinal was used as planting material. The crop was fertilized with 143-18-45-3-15-1.33-0.5 kg N-P-K-S-Mg-Zn-B $\mathrm{ha}^{-1}$. The entire amount of $\mathrm{P}, \mathrm{K}, \mathrm{S}, \mathrm{Mg}, \mathrm{Zn}$ and $1 / 2$ of $\mathrm{N}$ were applied during final land preparation. The rest nitrogen was top dressed at 35 DAP. Earthling up was done twice at 35 and 50 DAP. The crop was irrigated thrice at 35, 55 and 70 DAP. The crop was planted during 27 November, 2012 and 30 November, 2013. The crop was harvested on $1^{\text {st }}$ March $2013 \& 3^{\text {rd }}$ March, 2014, respectively. Data on yield and yield contributing characters were taken and analyzed statistically following MSTAT-C software package. Gross return (GR), total variable cost (TVC) and gross margin (GM) have been calculated using the following formula:

$\mathrm{GR}=$ Return of main product.

$=$ Yield Price $(\mathrm{Tk}$.)

$\mathrm{TVC}=\mathrm{All}$ input cost except land cost and interest on operating capital.

$\mathrm{GM}=\mathrm{GR}-\mathrm{TVC}$

\section{Results and Discussion}

The yield and yield contributing characters of different planting technique on tuber yield of potato are presented in Table $1 \&$ Table 2 . The highest plant height was found from half cut system and the lowest was from recommended planting system during both the year. The highest number of stem hill ${ }^{-1}$ and tuber hill $^{-1}$ was obtained from recommended planting 
system and the lowest was recorded from single eye double row zig-zag system during 2012-13 \& 201314. The highest tuber yield $\left(27.77 \mathrm{t} \mathrm{ha}^{-1)}\right.$ was obtained from recommended system of planting and the lowest yield was recorded from single eye double row zig-zag planting system (14.97 $\left.\mathrm{t} \mathrm{ha}^{-1}\right)$ during 2012-13. The highest tuber yield $\left(29.0 \mathrm{t} \mathrm{ha}^{-1)}\right.$ was obtained from recommended system of planting and the lowest yield was recorded from single eye planting system (22.57 $\mathrm{t} \mathrm{ha}^{-1}$ ) during 2013-14. The cost and return analysis of different planting technique on tuber yield of potato are presented in Table $3 \& 4$. The result indicated that the highest gross return (Tk.217500 ha ${ }^{-1}$ ) and gross margin $\left(\mathrm{Tk} .75000 \mathrm{ha}^{-1}\right)$ were obtained from recommended system of planting and the lowest gross return (Tk.127245 ha ${ }^{-1}$ ) and gross margin (Tk.7245 ha ${ }^{-1}$ ) were obtained from single eye double row zig zag system in both the year. The highest BCR was (1.46, 1.53 respectively, during 2012-13 \& 2013-14) found from recommended system of planting and the lowest (1.03, 1.06 respectively, during 2012-13 \& 2013-14) were obtained from single eye double row zig zag system in both the year.

Table 1. Yield Performance of planting technique on tuber yield of potato at MLT site Ulipur during Rabi season 2012-13

\begin{tabular}{|l|c|c|c|c|}
\hline Treatments & $\begin{array}{c}\text { Plant } \\
\text { height } \\
(\mathrm{cm})\end{array}$ & $\begin{array}{c}\text { No. of } \\
\text { Stem } \\
\text { hill }^{-1}\end{array}$ & $\begin{array}{c}\text { Tuber } \\
\text { hill }^{-1}\end{array}$ & $\begin{array}{c}\text { yield } \\
\left(\mathrm{t} \mathrm{ha}^{-1}\right)\end{array}$ \\
\hline $\begin{array}{l}\text { Recommended } \\
\text { system of } \\
\text { planting, }\end{array}$ & 46.87 & 5.03 & 5.23 & 27.77 \\
\hline $\begin{array}{l}\text { Single eye } \\
\text { planting, }\end{array}$ & 50.87 & 3.13 & 3.17 & 16.73 \\
\hline $\begin{array}{l}\text { Single eye } \\
\text { double row zig } \\
\text { zag system }\end{array}$ & 50.53 & 2.67 & 2.67 & 14.97 \\
\hline Half cut system & 53.73 & 4.37 & 3.93 & 21.90 \\
\hline \multicolumn{1}{|l}{ LSD Value } & 4.14 & 0.64 & 0.75 & 1.74 \\
\hline \multicolumn{1}{c}{ CV (\%) } & 2.71 & 5.50 & 6.77 & 2.83 \\
\hline
\end{tabular}

\section{Disease-Pest Infestation}

The Potato field was broadcasted with Furadan ( $10 \mathrm{~kg} \mathrm{ha}{ }^{-1}$ during final land preparation avoid common cutworm and ant infestation. After emergence, cutworm infestation was observed and the field was sprayed with Ralothrin @ $2 \mathrm{mlL}^{-1}$ at evening. Late blight disease was observed in the mid of December in the nearby field. To control late blight, Dithane-M@4gL-1 of water was sprayed after 25 DAP and Acrovate MZ@ 2.0 g/liter of water was sprayed at the later stage of crop growth.

Table 2. Yield Performance of planting technique on tuber yield of potato at MLT site Ulipur during Rabi season 2013-14

\begin{tabular}{|l|c|c|c|c|}
\hline \multicolumn{1}{|c|}{ Treatments } & $\begin{array}{c}\text { Plant } \\
\text { height } \\
(\mathrm{cm})\end{array}$ & $\begin{array}{c}\text { No. of } \\
\text { Stem } \\
\text { hill }^{-1}\end{array}$ & $\begin{array}{c}\text { Tuber } \\
\text { hill }^{-1}\end{array}$ & $\begin{array}{c}\text { yield (t } \\
\left.\text { ha }^{-1}\right)\end{array}$ \\
\hline $\begin{array}{l}\text { Recommended } \\
\text { system of } \\
\text { planting, }\end{array}$ & 61.60 & 3.733 & 7.30 & 29.0 \\
\hline $\begin{array}{l}\text { Single eye } \\
\text { planting, }\end{array}$ & 55.67 & 2.20 & 4.90 & 22.57 \\
\hline $\begin{array}{l}\text { Single eye } \\
\text { double row zig } \\
\text { zag system }\end{array}$ & 55.90 & 2.133 & 3.33 & 23.67 \\
\hline $\begin{array}{l}\text { Half cut } \\
\text { system }\end{array}$ & 53.17 & 2.267 & 3.367 & 24.83 \\
\hline LSD Value & 1.71 & 0.61 & 1.33 & 0.71 \\
\hline CV (\%) & 1.52 & 11.81 & 14.09 & 1.43 \\
\hline
\end{tabular}

Disease infestation percentage was found in higher from treatment single eye planting and single eye double row zig-zag system both the year 2012-13 \& 2013-14. But in lowest disease was recorded from recommended planting system during 2012-13 \& 2013-14 Table 5. Grading of potato from the different treatment show at Table 6 the highest percentage of grade-A found from half cut planting system and the lowest was recorded from recommended planting system in both the year. The highest number of potato grade-B obtained from recommended planting system and the lowest was found from single eye planting system during 2012$13 \&$ 2013-14 both the year.

\section{Conclusion}

In review of the result of the study, it was observed that highest tuber yield was obtained from recommended system of planting technique on tuber yield of Potato. The economic performance of this technique was also better compared to other technique under this study. 
Table 3. Cost and return of planting technique on tuber yield of potato at MLT site Ulipur during Rabi season 2012-13.

\begin{tabular}{|l|c|c|c|r|c|}
\hline Treatments & $\begin{array}{c}\text { Yield } \\
\left(\mathrm{t} \mathrm{ha}^{-1}\right)\end{array}$ & $\begin{array}{c}\text { Gross return } \\
\left(\text { Tk.ha }^{-1}\right)\end{array}$ & $\begin{array}{c}\text { TVC (Tk.ha } \\
\left.{ }^{1}\right)\end{array}$ & $\begin{array}{c}\text { Gross } \\
\text { margin }\end{array}$ & BCR \\
\hline Recommended system of planting & 27.77 & 201333 & 143250 & 58083 & 1.46 \\
\hline Single eye planting, & 16.73 & 121293 & 120250 & 1043 & 1.00 \\
\hline Single eye double row zig zag system & 14.97 & 108533 & 105125 & 3408 & 1.03 \\
\hline Half cut system & 21.90 & 158775 & 122500 & 36275 & 1.29 \\
\hline
\end{tabular}

Potato $=$ Tk. $7.25 \mathrm{~kg}^{-1}$, Urea $=$ Tk. $20 \mathrm{~kg}^{-1}, \mathrm{TSP}=\mathrm{Tk} .25 \mathrm{~kg}^{-1}, \mathrm{MP}=\mathrm{Tk} .15 \mathrm{~kg}^{-1}$, Zinc sulphate $=\mathrm{Tk} .160 \mathrm{~kg}^{-1}$, Boric acid $=\mathrm{Tk} \cdot 150 \mathrm{~kg}^{-1}$, $\mathrm{Lab}=\mathrm{Tk} .200 \mathrm{day}^{-1}$, Gypsum $=\mathrm{Tk} \cdot 10 \mathrm{~kg}^{-1}$

Table 4. Cost and return of planting technique on tuber yield of potato at MLT site Ulipur during Rabi season 2013-14.

\begin{tabular}{|l|c|c|c|c|c|}
\hline Treatments & $\begin{array}{c}\text { Yield } \\
\left(\mathrm{t} \mathrm{ha}^{-1}\right)\end{array}$ & $\begin{array}{c}\text { Gross return } \\
\left(\text { Tk.ha }^{-1}\right)\end{array}$ & $\begin{array}{c}\text { TVC } \\
\left(\text { Tk.ha }^{-1}\right)\end{array}$ & $\begin{array}{c}\text { Gross margin } \\
\left(\text { Tk.ha }^{-1}\right)\end{array}$ & BCR \\
\hline Recommended system of planting & 29.00 & 217500 & 142500 & 75000 & 1.53 \\
\hline Single eye planting, & 22.57 & 142205 & 123750 & 18455 & 1.15 \\
\hline Single eye double row zig zag system & 23.67 & 127245 & 120000 & 7245 & 1.06 \\
\hline Half cut system & 24.83 & 186150 & 127500 & 58650 & 1.46 \\
\hline
\end{tabular}

Potato $=$ Tk. $7.50 \mathrm{~kg}^{-1}$, Urea $=$ Tk. $20 \mathrm{~kg}^{-1}, \mathrm{TSP}=\mathrm{Tk} .25 \mathrm{~kg}^{-1}, \mathrm{MP}=\mathrm{Tk} .15 \mathrm{~kg}^{-1}$, Zinc sulphate $=\mathrm{Tk} .160 \mathrm{~kg}^{-1}$, Boric acid $=\mathrm{Tk} .150 \mathrm{~kg}^{-1}$, $\mathrm{Lab}=\mathrm{Tk} .200 \mathrm{day}^{-1}$, Gypsum $=\mathrm{Tk} \cdot 10 \mathrm{~kg}^{-1}$

Table 5. Disease infection percentage of late blight and scab during 2012-13 and 2013-14

\begin{tabular}{|c|c|c|c|c|}
\hline \multirow{2}{*}{ Treatments } & \multicolumn{2}{|c|}{ Late blight } & \multicolumn{2}{c|}{ Scab (\%) } \\
\cline { 2 - 5 } & $2012-13$ & $2013-14$ & $2012-13$ & $2013-14$ \\
\hline $\mathrm{T}_{1}$ & 5 & 4 & 3 & 2 \\
\hline $\mathrm{T}_{2}$ & 12 & 10 & 10 & 8 \\
\hline $\mathrm{T}_{3}$ & 10 & 9 & 10 & 8 \\
\hline $\mathrm{T}_{4}$ & 7 & 7 & 8 & 5 \\
\hline
\end{tabular}

Table 6. Grading percentage of the potato under different treatment during 2012-13 and 2013-14

\begin{tabular}{|l|l|l|l|l|l|l|l|l|}
\hline \multirow{3}{*}{ Grade } & \multicolumn{9}{|c|}{ Grade } & \multicolumn{2}{c|}{ B } & \multicolumn{2}{c|}{ Over } \\
\cline { 2 - 10 } & \multicolumn{2}{|c|}{ Below } & \multicolumn{2}{|c|}{ A } & \multicolumn{2}{c|}{ B } \\
\cline { 2 - 10 } & $2012-13$ & $2013-14$ & $2012-13$ & $2013-14$ & $2012-13$ & $2013-14$ & $2012-13$ & $2013-14$ \\
\hline $\mathrm{T}_{1}$ & 5 & 7 & 33 & 39 & 52 & 46 & 10 & 8 \\
\hline $\mathrm{T}_{2}$ & 55 & 57 & 39 & 38 & 5 & 2 & 1 & 3 \\
\hline $\mathrm{T}_{3}$ & 46 & 49 & 46 & 44 & 7 & 5 & 1 & 2 \\
\hline $\mathrm{T}_{4}$ & 9 & 11 & 55 & 63 & 34 & 25 & 2 & 1 \\
\hline
\end{tabular}




\section{References}

Ali, M. S. and Haque, A.2011. Potato for food Security in SAARC Countries; SAARC. Seed Congress and Fair 2011, Dhaka, Bangladesh.

BBS (Bangladesh Bureau of Statistics). 2009. Yearbook of Agricultural Statistics in Bangladesh, Bangladesh Bureau of Statistics, Ministry of Planning, Government of the People's Republic of Bangladesh, Dhaka.

DAE (Department of Agricultural Extension). 2010. Agricultural Extension Manual, Khamarbari, Farmgate, Dhaka.

FAO (1986) Agricultural production yearbook. FAO Statistics Series, 36, 126-127.

Gandapur, A.K. (1995) Evaluation of potato varieties in Hazara. M.Sc. (Hons) Thesis, Department of Plant Breeding and Genetics, NWFP Agricultural University, Peshawar.

Horton, D. (1987) Potatoes: Production, marketing, and programs for developing countries. Westview Press, Colorado, 244.

Ivins, J.D. and Milthope, F.L. (1963) The growth of potatoes. Butterwoyhs, London, 328.

Maikhuri, R.K., Rao, K.S. and Saxena, K.G. (1996) Traditional crop diversity for sustainable development of central Himalayan agroecosystems. International Journal of Sustainable Development \& World Ecology, 3, 8- 31. doi:10.1080/13504509609469926

Mondal. M.A.A. 2003. Improvement of potato (SolanumtuberosumL.) through hybridization and in vitro culture technique. Ph.D. Thesis, Rajshahi University, Rajshahi, Bangladesh.

Sarker RH and Mostafa BM. 2002. Regeneration and agro bacterium mediated genetic transformation of two indigenous potato varieties of Bangladesh Plant Tiss.Cult.12 (1):69-77.

Van Der Zaag, D. and Horton, D. (1983) Potato production and utilization in world perspective with special reference to the tropics and subtropics. Potato Research, 26, 323-362. doi:10.1007/BF02356154

Woolfe, J.A. (1987) The potato in the human diet. Cambridge University Press, Cambridge, 231. 